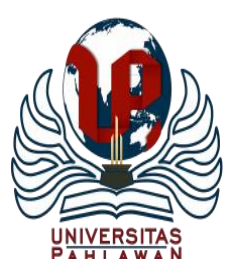

Jurnal Abdidas Volume 1 Nomor 4 Tahun 2020 Halaman 234 - 241

JURNAL ABDIDAS

Community Development Service on Educational and Health Sciences

http://abdidas.org/index.php/abdidas

\title{
Pendampingan Mendesain Tabungan Sederhana sebagai Solusi Kesadaran Menabung bagi Anak Usia Sekolah Dasar di Deli Serdang
}

\author{
Eko Febri Syahputra Siregar ${ }^{1}$, Masta Sembiring ${ }^{2}$, Ismail Saleh Nasution ${ }^{3}$ \\ Universitas Muhammadiyah Sumatera Utara ${ }^{1,2,3}$

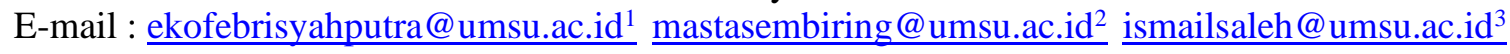

\begin{abstract}
Abstrak
Artikel ini membahas tentang pendampingan mendesain tabungan sederhana sebagai solusi kesadaran menabung bagi anak. Pengabdian ini mengambil objek anak-anak usia sekolah yang senang menghabiskan waktu dan uangnya di warung internet (warnet). Anak-anak tersebut tidak memperhatikan waktu apabila sudah berada di warnet. Para anak tersebut diberikan beberapa kegiatan diantaranya sosialisasi cita-cita, bimbingan belajar, mengaji selepas magrib dan mendesaian tabungan secara sederhana. Kegiatan utama pada pengabdian ini adalah mendesain tabungan sederhana. Manfaat diadakan kegiatan ini adalah : 1) menghilangkan kebiasaan anak-anak bermain ke warnet, 2) meningkatakan kesadaran anak-anak untuk hidup hemat dengan mengutamakan menabung untuk mempersiapkan masa depan dan 3) membiasakan pola hidup sehat dengan tidak jajan sembarangan. Metode yang dilakukan pada kegiatan ini adalah pendampingan dalam hal mendesaian tabungan sederhana. Berdasarkan hasil pendampingan yang dilakukan, diperoleh hasil bahwa setiap anak memiliki cita-cita yang bagus di masa depan, diperlukan adanya pendampingan dalam hal akademik untuk mencapai cita-cita tersebut dan seorang anak memiliki tingkat keseriusan yang tinggi apabila mengerjakan sesuatu sesuai keinginan (minat dan bakat) tanpa adanya paksaan ataupun campur tangan dari pihak manapun.
\end{abstract}

Kata kunci: pendampingan,mendesain tabungan, kesadaran menabung

\begin{abstract}
This article discusses the assistance of designing simple savings as a solution to saving awareness for children. This dedication takes the object of school-age children who like to spend their time and money in internet cafes. The children do not pay attention to the time when they are in the cafe. The children were given several activities including socializing ideals, tutoring, studying after sunset and designing savings in a simple way. The main activity in this service is designing simple savings. The benefits of holding this activity are: 1) eliminating the habit of children playing in internet cafes, 2) increasing children's awareness to live frugally by prioritizing saving to prepare for the future and 3) familiarizing healthy lifestyles by not eating at random. The method used in this activity is assistance in terms of designing simple savings. Based on the results of assistance provided, the results obtained that each child has good ideals in the future, it is necessary to have assistance in academic matters to achieve these goals and a child has a high level of seriousness when doing something according to your wishes (interests and talents ) without coercion or interference from any party.
\end{abstract}

Keywords: assistance, designing savings, saving awareness

Copyright (c) 2020 Eko Febri Syahputra Siregar, Masta Sembiring, Ismail Saleh Nasution

$\triangle$ Corresponding author:

Address : Universitas Muhammadiyah Sumatera Utara

Email : ekofebrisyahputra@umsu.ac.id

ISSN 2721- 9224 (Media Cetak)

Phone : -

ISSN 2721- 9216 (Media Online)

DOI: https://doi.org/10.31004/abdidas.v1i4.50 

Nasution

DOI: https://doi.org/10.31004/abdidas.v1i4.50

\section{PENDAHULUAN}

Desa Durian, Kecamatan Pantai Labu, Kabupaten Deli Serdang, Sumatera Utara memiliki potensi yang sangat baik dalam bidang pendidikan. Setidaknya ada beberapa lembaga pendidikan yang terdapat di Desa Durian yang terdiri atas SD/MI, SMP maupun SMA/SMK. SD/MI yang terdapat di Desa ini sebanyak 6 (enam) sekolah, SMP sebanyak 1 (satu) sekolah dan SMK sebanyak 1 (satu) sekolah. Melihat perseberan jumlah lembaga pendidikan yang cukup tersebut, maka tentunya ini memberikan jaminan tersendiri bagi anak-anak yang ada di Desa Durian untuk tidak putus sekolah.

Banyaknya lembaga pendidikan diimbangi juga dengan banyaknya populasi warung internet (warnet) yang berdiri di desa ini. Pada dasarnya, lembaga pendidikan tersebut memiliki peran yang sangat penting, seperti dijelaskan oleh Siregar (2018), pendidikan bukan hanya menyiapkan masa depan, tetapi juga bagaimana menciptakan masa depan.

Warnet melaui jaringan internetnya di masa sekarang ini memiliki pengaruh yang besar dalam menentukan keberlangsungan hidup generasi penerus bangsa ini. Pengaruh tersebut dapat bernilai positif maupun negatif. Padahal apabila digunakan sebagaimana fungsinya tentunya internet memiliki dampak positif bagi siswa seperti untuk mencari referensi tugas yang diperlukan serta mengenalkan siswa akan dunia luar sebagai khasanah pengetahuan, namun apabila tidak digunakan sesuai fungsinya maka akan membawa dampak negatif bagi siswa, seperti bermain game online yang berlebihan dan membuka situs yang tidak baik.

Berdasarkan hasil observasi dan wawancara yang dilakukan tim pelaksana sebelum kegiatan pengabdian dilaksanakan, kebanyakan anak usia sekolah di Desa Durian yang datang ke warnet bukan untuk mencari tugas dari sekolah, melainkan untuk bermain game online. Seorang anak tidak peduli berapa banyak uang yang dihabiskan untuk bermain game online, bahkan tidak sadar sudah berjam-jam di warnet. Padahal apabila uang yang digunakan untuk bermain game online ditabung, dapat membantu mereka untuk membeli apa yang dibutuhkan dalam pembelajaran bahkan dapat digunakan untuk mencapai cita-cita yang diinginkan. Menurut Majid (2016) menyatakan bahwa masalah yang paling mendasar adalah banyaknya anak yang lebih suka menghabiskan uang jajan dari pada menabungkan sisa uang sakunya, bahkan beberapa di antara mereka masih meminta uang lagi untuk membeli mainan.

Kegiatan menabung secara tidak langsung banyak mendidik anak dalam hal kehidupan, yaitu melatih anak untuk hidup hemat dan menahan keinginan dari pada kebutuhan, melatih anak untuk hidup sehat dengan tidak menggunakan uang saku untuk sembarang membeli jajanan, kemudian melatih anak untuk menyusun masa depan yang lebih baik dengan memulai sejak usia sekolah.

Salah satu solusi yang dapat dilakukan untuk mengurangi kebiasaan bermain ke warnet serta menanmkan pola hidup hemat pada diri siswa adalah meningkatkan kesadaran dalam menabung 

Nasution

DOI: https://doi.org/10.31004/abdidas.v1i4.50

bagi seorang anak dengan mengajak mereka mendesain tabungan sesuai keinginan mereka. Sehingga dengan tindakan seperti itu ada rasa kecintaan dan menghargai terhadap produk yang mereka hasilkan dengan tangan mereka sendiri, sehingga mereka akan terus mengisi tabungan yang di desain sendiri dengan sisa uang saku mereka.

\section{METODE}

Kegiatan pengabdian ini dilaksanakan dengan menggunakan metode PAR yaitu Participatory Action Reach. Participatory yang dimaksud adalah paristisipasi atau turut serta, Action adalah aksi atau kegiatan, sedangkan Research adalah penelitian. Menurut Reason \& Bradbury (2008) dalam Adhi Iman Sulaiman, Masrukin \& Adhi (2019) Metode kualitatif Participatory Action Research (PAR) yaitu penelitian yang melibatkan partisipasi pihak yang berkaitan secara aktif dan bersama-sama melakukan tindakan untuk mengatasi atau memperbaiki masalah yang dialami berdasarkan pertimbangan kritis historis, politik, budaya, ekonomi, geografis dan konteks lainnya. Pelaksana dalam kegiatan ini berperan sebagai fasilitator dan pendamping kelompok sasaran untuk bersamasama melakukan kegiatan yang telah direncanakan, artinya tidak memisahkan dari dari kegiatan ini dan terlibat aktif. Menurut ZuberSkerritt (1993) terdapat empat tema dasar dalam PAR, yaitu kolaborasi melalui partisipasi, mendapat pengetahuan, dan perubahan sosial. Proses tersebut diperoleh melalui tahapan diantaranya perencanaan, tindakan, pengamatan dan refleksi. Penelitian PAR memiliki tujuan, yaitu 1) membangun kesadaran atau memberdayakan masyarakat melalui pendidikan kritis dengan berdialog, diskusi publik dan mengarah pada pembelajaran orang dewasa; 2) menggubah cara pendang penelitian menjadi sebuah proses partisipasi aktif; dan 3) membawa pada perubahan sosial.

Adapun kegiatan yang direncanakan untuk mencapai target yang diinginkan, yaitu;

1) Sosialisasi "Cita-Citaku"

Sosialisasi ini dimaksud untuk membuka wawasan anak tentang hal yang menjadi citacita mereka serta cara meraih cita-cita yang diinginkan. Dengan memberikan materi ini, secara perlahan pelaksana merangsang anak untuk giat belajar dan mengurangi aktifitasnya di warnet agar fokus kepada hal yang menjadi cita-citanya.

2) Bimbingan Belajar

Yaitu belajar bersama para pelaksana selepas pulang sekolah di pemondokan pelaksana. Hal ini dilakukan guna meningkatkan pemahaman anak terhadap materi yang kurang dipahami saat belajar di sekolah serta secara tidak langsung mengurangi kebiasaan anak untuk bermain game online di warnet. Pada bimbingan belajar ini Bimbingan belajar dilaksanakan setiap hari kecuali hari minggu pada pukul 15.00 sampai 17.00 WIB.

3) Mengaji Selepas Magrib

Merupakan kelanjutan dari kegiatan bimbingan belajar. Namun kegiatan ini dilakukan di 

Usia Sekolah Dasar di Deli Serdang - Eko Febri Syahputra Siregar, Masta Sembiring, Ismail Saleh Nasution

DOI: https://doi.org/10.31004/abdidas.v1i4.50

mushollah yang terdapat disekitar pemondokan.

Kegiatan ini bertujuan untuk mengajarkan anak untuk mendekatkan diri kepada Allah SWT serta menanamkan nilai-nilai islami yang haris diterapkan dalam kegiatan sehari-hari.

4) Mendesain Tabungan

Merupakan kegiatan induk dari solusi penyelesaian masalah ini. Dengan mengikuti sosialisasi cita-citaku, bimbingan belajar dan kegiatan mengaji selepas magrib, tentunya mengurangi waktu anak-anak untuk pergi ke warnet dan secara otomatis uang yang mereka miliki masih tetap utuh, sehingga dapat ditabung pada tabung yang akan diberikan oleh pelaksana. Namun sebelum itu, anak-anak diberikan kebebasan untuk mewarnai kertas yang akan ditempelkan pada tabungan yang mereka miliki. hal ini bertujuan agar adanya rasa sayang dan memiliki atas tabungan yang sudah mereka desain. Harapannya adalah uang yang mereka tabung nantinya dapat digunakan untuk membeli kebutuhan sekolah bahkan untuk mencapai cita-cita yang diinginkan.

Upaya tersebut dicapai dalam bentuk pengabdian yang melibatkan 30 (tiga puluh) mahasiswa Universitas Muhammadiyah Sumatera Utara (UMSU) dari berbagai program studi sebagai tim pelaksana. Keseluruhan mahasiswa tersebut dibagi menjadi 3 (tiga) kelompok yang berada pada dusun yang berbeda-beda yaitu Dusun IIA, III dan VA dengan pembagian masing-masing kelompok sebanyak 10 (sepuluh) orang mahasiswa dengan durasi waktu kegiatan selama kurang lebih 30 (tiga puluh) hari dan mereka dalam kelompok masing-masing berperan sebagai motivator, fasilitator, dan dinamisator bagi para sasaran.

Kegiatan ini dilaksanakan pada hari Kamis tanggal 22 Agustus 2019. Adapun yang menjadi sasaran kegiatan ini adalah anak-anak usia Sekolah Dasar (SD) sebanyak 25 (dua puluh lima) orang yang mengikuti kegiatan rutin pengajian di mushollah sekitar posko tim pelaksana.

\section{HASIL DAN PEMBAHASAN}

Kegiataan pengabdian yang dilaksanakan berjalan dengan lancar selama 30 (tiga puluh) hari terhitung sejak pra pelaksanaan, pelaksanaan dan pasca pelaksanaan. Kegiatan yang dilaksanakan oleh 2 (dua) orang Dosen Pendamping Lapangan (DPL) dan 30 (tiga puluh) mahasiswa ini mampu memenuhi solusi penyelesaian masalah yang menjadi target dari kegiatan pengabdian ini.

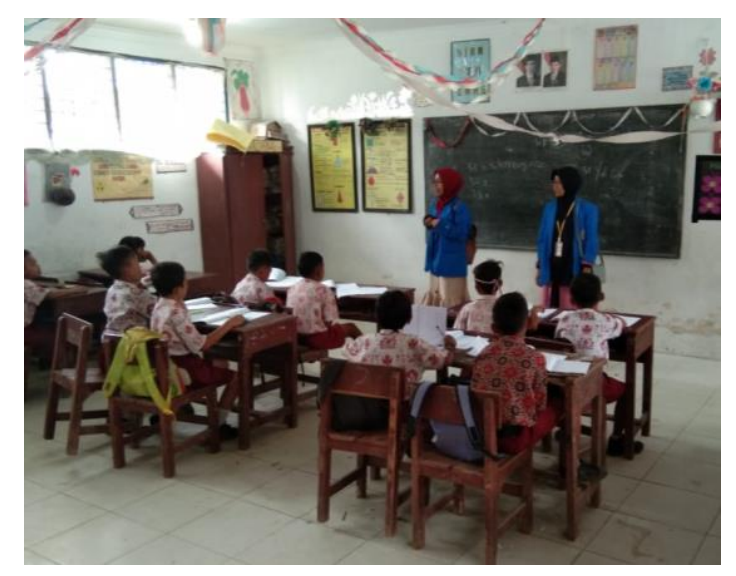

Gambar 1. Sosialisasi "Cita-Citaku" di Salah Satu SD Negeri di Desa Durian

Adapun kegiatan yang berhasil dilaksanakan, yaitu: pertama, Sosialisasi "CitaCitaku", dengan metode sosialisasi yang diberikan secara belajar sambil bermain disisipkan dengan 

Usia Sekolah Dasar di Deli Serdang - Eko Febri Syahputra Siregar, Masta Sembiring, Ismail Saleh Nasution

DOI: https://doi.org/10.31004/abdidas.v1i4.50

game seru karya mahasiswa dan adanya reward sederhana, pelaksana berhasil memperoleh informasi terkait cita-cita yang dimili anak-anak Desa Durian dan untuk menggapai cita-cita yang dikehendaki, diperlukan persiapan yang matang salah satunya melalui nilai akademik. Di saat sharing ringan, pelaksana juga berhasil mengetahui kelemahan anak-anak Desa Durian dalam sisi akademik, sehingga kelemahan ini dijadikan modal untuk melaksanakan kegiatan Bimbingan Belajar bagi siswa.

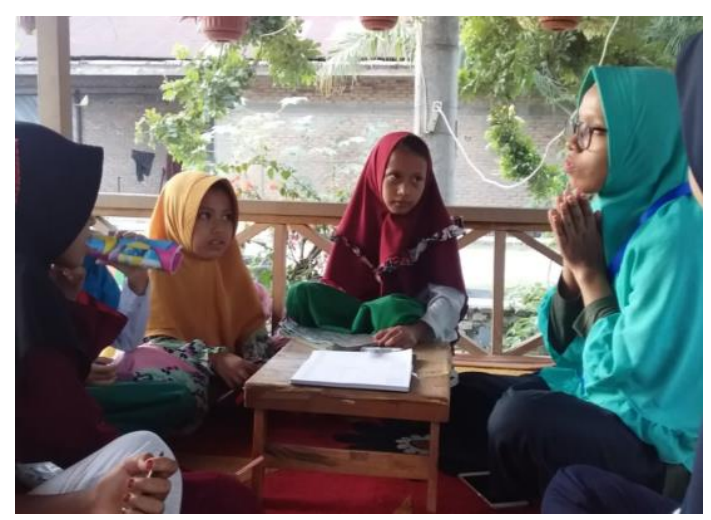

Gambar 2. Bimbingan Belajar dilakukan di Pemondokan Pelaksana

Kedua, Bimbingan Belajar. Pelaksana menyesuaikan hal yang menjadi kesulitan anak dalam menguasai materi serta mata pelajaran yang dianggap sulit. Metode yang dilaksanakan pada kegiatan ini yaitu belajar dengan disisipkan menonton video motivasi dan ice breaking. sehingga anak-anak tidak mengalami hal yang monoton. Pelaksana juga menggunakan cara-cara tertentu untuk meningkatkan motivasi peserta, yaitu dengan cara menyiapkan simbol-simbol untuk anak yang berhasil menjawab ataupun menyelesaikan soal yang diberikan oleh pelaksana dengan tepat waktu.

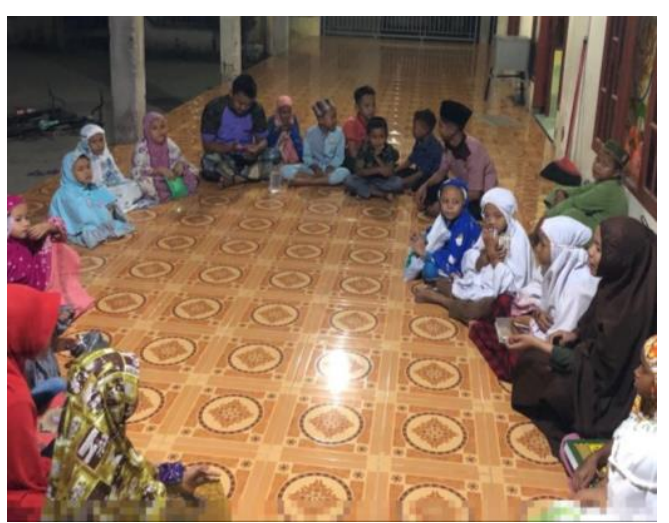

Gambar 3. Mengaji yang dilakukan Selepas Ashar

Ketiga, Mengaji Selepas Magrib. Programprogram yang terdapat pada kegiatan ini, yaitu mengaji Iqro' dan Al-qur'an serta ada juga kegiatan setor hafalan surat pendek. Pelaksana juga melatih keberanian dan rasa percaya diri anak-anak untuk berbicara didepan umum melalui kegiatan Kuliah Tujuh Menit (Kultum) yang dilakukan oleh seorang anak setiap malamnya di penghujung pengajian.

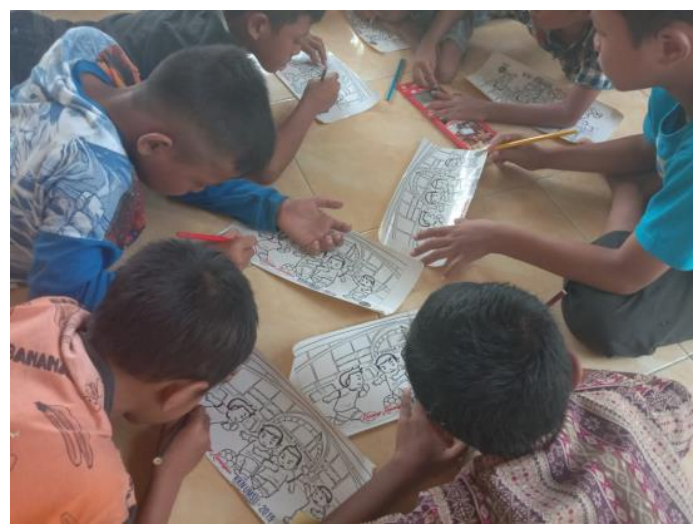

Gambar 4. Mendesain Tabungan Secara Sederhana 

Nasution

DOI: https://doi.org/10.31004/abdidas.v1i4.50

Keempat, Mendesain Tabungan. Pada saat mengikuti kegiatan ini terlihat sangat jelas bahwa anak-anak sangat senang dan menikmati kegiatan ini. Mereka terlihat serius seperti tidak mau diganggu untuk meyelesaikan produk mereka. Pada sesi ini, anak-anak diberikan kebebasan untuk mewarnai kertas sticker sesuai keinginan mereka tanpa ada batasan dan campur tangan orang lain.

Kertas sticker tersebut sengaja ditempah oleh tim pelaksana dengan gambar yang bervariasi dengan tidak meninggalkan identitas asal tim peneliti yaitu berupa logo Universitas Muhammadiyah Sumatera Utara (UMSU) yang dapat dijadikan kenang-kenangan. Setelah diwarnai oleh peserta kegiatan, kemudian ditempelkan pada kaleng yang telah disediakan oleh para pelaksana. Kegiatan ini merupakan kegiatan unggulan yang dilaksanakan oleh tim pelaksana karena diharapkan dampak dari kegiatan ini dapat menanamkan kebiasaan pada diri anak dalam mengurangi perilaku hidup konsumtif dan memiliki kebiasaan menabung.

Menabung bagi orang dewasa terkesan sepele, namun bagi usia anak-anak memiliki pengaruh yang besar guna mencapai cita-cita mereka. Belum lagi tabungan yang mereka gunakan adalah tabungan dengan desain yang dilakukan oleh mereka sendiri. Anak-anak pada umumnya tidak suka dibatasi dalam berekspresi untuk menuangkan kreatifitas mereka karena dengan mereka berekspresi mereka berhasil menemukan jati diri yang terdapat dalam diri mereka.
Menurut Krisdayanthi (2019) pendidikan tentang pengelolaan keuangan (menabung) sangat dibutuhkan untuk meminimalisir kemiskinan akibat pola hidup konsumtif dan peran orang tua menjadi sangat penting untuk mencapai kesejahteraan anak pada saat dewasa nantinya. Hal yang sama juga diungkapkan Soviah (2019) bahwa menabung sejatinya ditanamkan kepada anak sejak dini, baik oleh orangtua (keluarga), guru (sekolah) maupun oleh lembaga keuangan seperti bank. Sejalan dengan pernyataan tersebut, Marlina \& Iskandar (2019) menanamkan minat menabung pada anak sejak usia dini diharapkan mampu menumbuhkan kembali kebiasaan menabung pada generasi muda Indonesia selanjutnya yang pada akhirnya mampu memberikan kontribusi bagi bangsa dan negara. Menabung berarti menyisihkan sebagian uang yang dimiliki untuk disimpan. Memiliki kebiasaan menabung sudah jelas sangat berguna untuk masa depan.

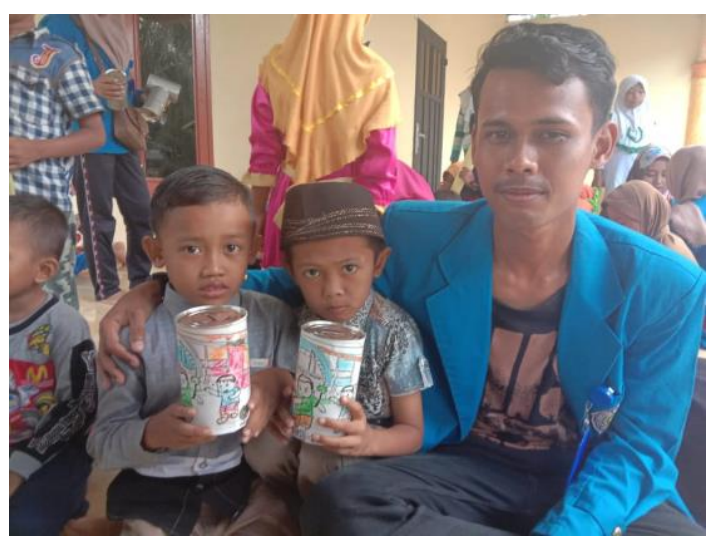

Gambar 5. Hasil Tabugan yang Sudah di Desain

Pada saat mendesain tabungan, sesungguhnya bukan hanya pengetahuan (kognitif) anak saja yang terlibat didalamnya tetapi 
keterampilan (motorik) dan sikap (afektif) juga terkembangkan. Dalam hal pengetahuan, anak memahami manfaat dan kegunaan dari tabungan yang sudah didesain secara individual, sedangkan dalam hal penanaman sikap yaitu mengembangkan pola hidup hemat dalam diri anak untuk memperoleh kehidupan yang lebih baik dimasa depan serta dalam hal keterampilan yaitu anak menjadi lebih kreatif dalam menyusun hal yang menjadi kebutuhan sesuai dengan keinginannya tanpa adanya paksaan yang ditanamkan.

\section{SIMPULAN}

Kesimpulan kegiatan pengabdian ini yaitu kegiatan terlaksana dengan lancar dan dibuktikan dengan tercapainya hal yang dikehendaki. Pada umumnya setiap kegiatan yang direncanakan dapat terlaksana dengan baik, diantaranya peningkatan keimanan dan ketaqwaan kepada Allah SWT melalui rutinitas kegiatan pengajian yang dilaksanakan di mushollah sekitar posko tim pelaksana. Peningkatan motivasi belajar anakanak, terihat dari aktivitas belajar tambahan (bimbel) di posko tim pelaksana yang diikuti anakanak setiap sore. Peningkatan pola hidup sehat dengan cara mengurangi kebiasaan membeli jajan sembarangan serta peningkatan kesadaran akan pentingnya menabung guna menanmkan pola hidup hemat serta mencapai kesuksesan di masa depan.

Kebiasaan menabung anak-anak masih tergolong sangat rendah dan perlu adanya pengawasan yang dilakukan oleh orang tua agar anak mereka memiliki kebiasaan menabung yang tinggi. Selain orang tua, stakeholder di Desa yaitu Pemerintah Desa Durian selaku pemangku kepentingan diharapkan dapat menindaklanjuti kegiatan menabung pada anak-anak di lingkungannya misalnya dengan cara mendirikan Badan Usaha Milik Desa (BUMDesa) dengan jenis usaha simpan pinjam. Usaha ini menyediakan tempat sebagai sarana penyimpanan uang anakanak dan uang tersebut dapat dipinjamkan kepada warga yang membutuhkan untuk modal usaha guna menigkatkan perekonomian warga desa. Contoh lain juga yang dapat dilakukan oleh Pemerintah Desa, yaitu Pendirian Bank Sampah dengan program tabungan sampah. Pemerintah dapat menerima tabungan anak-anak dalam bentuk barang bekas yang memiliki nilai jual. Hasil penjualan dapat ditukar dengan uang yang kemudian dapat ditabung oleh anak-anak. Maka dari itu upaya mendorong kebiasaan tersebut dan sinergitas antara Pemerintahan Desa, Masyarakat, Tokoh Masyarakat, Tokoh Agama dan Tokoh Pemuda serta Dosen Pendamping Lapangan kegiatan ini serta para mahasiswa khususnya.

\section{DAFTAR PUSTAKA}

Adhi Iman Sulaiman, Masrukin, \& B., \& Adhi. (2019). Pemberdayaan Masyarakat Pesantren dalam Kewirausahaan dan Koperasi. Prosiding Seminar Nasional Dan Cal Papers, 5(November), 12-26.

Krisdayanthi, A. (2019). Penerapan Financial Parenting (Gemar Menabung) Pada Anak Usia Dini. Pratama Widya: Jurnal Pendidikan Anak Usia Dini, 4(1), 1. https://doi.org/10.25078/pw.v4i1.1063

Majid, A. (2016). Menumbuhkan Minat Menabung Pada Anak Usia Dini Melalui Perancangan 
241 Pendampingan Mendesain Tabungan Sederhana sebagai Solusi Kesadaran Menabung bagi Anak Usia Sekolah Dasar di Deli Serdang - Eko Febri Syahputra Siregar, Masta Sembiring, Ismail Saleh Nasution

DOI: https://doi.org/10.31004/abdidas.v1i4.50

Game Edukasi.

Marlina, N., \& Iskandar, D. (2019). Gerakan Menabung Sejak Dini di Rowosari. Pengabdian Vokasi, 01(01), 27-32.

Siregar, E. F. S. (2018). Pengaruh Model Project Based Learning Dan Motivasi Belajar Terhadap Hasil Belajar IPS Siswa Di Kelas IV SD Negeri 104188 Medan Krio Tahun Ajaran 2017 / 2018. BINA GOGIK, 5(2).

Soviah, O. F. (2019). Penyuluhan Membangun Kesadaran Menabung Sejak Dini Pada Siswa Sdn 2 Lengkong Wetan Kelurahan. September.

Zuber-Skerritt, O. (1993). Improving Learning and Teaching Through Action Learning and Action Research. Higher Education Research \& Development, 12(1), 45-58. https://doi.org/10.1080/0729436930120105 